\title{
Empirical Analysis of the Relationship between Organizational Culture and Organizational Performance
}

\author{
Zhipeng ZHANG \\ School of Management, Dalian Polytechnic University, \\ Dalian, China \\ zzpsg@163.com
}

\begin{abstract}
This article uses empirical research to analyze four types of organizational culture on organizational performance, the results show that: adhocracy culture and market culture have a positive impact on financial performance and market performance, clan culture and hierarchy culture have a negative impact on financial performance and market performance, And adhocracy and market had greater impact on organizational performance.
\end{abstract}

Keywords-organizational culture; organization alperformance; empirical; analysis

Since the 1980s,the organizational culture was seen as the key of the internal integration of business and the adaptation of the changes in the external environment when it has been proposed as a new discipline. Today, almost no business management practices will ignore the importance of organizational culture, for instance: Citibank's people-oriented strategy; Hewlett-Packard Company's HP Way culture; Lenovo's clan Culture; International Business Machines Corporation's Remarkable business ethics and so on. Rand Corporation, and other international management consulting firm McKinsey study found that the role of corporate culture are very obvious in brilliant performance of the company, The results which studied by domestic and foreign scholars show that organizational culture has a significant impact on organizational performance. However, this result is mainly obtained through case studies, rarely scholars use empirical research methods to illustrate how organizational culture can affect organizational performance. Based on this, this paper argues the relationship between organizational culture and organizational performance by empirical research methods.

\section{Theory and Hypotheses}

\section{A Organizational performance}

Organizational performance is the degree of achieving specific goals, it usually consists of a number of indicators to measure the efficiency and effectiveness of the organization, in order to understand whether the process of its operation is accord with the established goals. Selecting the appropriate performance indicators that can reflect the objective existence of the organization's various activities in the value of strategy and necessity, and thus provide guidance for management decisions. However, until today, the determination of

\author{
Xiancheng ZHU \\ School of Management, Dalian Polytechnic University, \\ Dalian, China
}

performance indicators is still in the process of discussion, and there hasn't a complete index system which was recognized by people.

Generally, the indicators of organizational performance assessment can be divided into non-financial indicators and financial indicators. Financial indicators is the most basic method of judging organizational performance, it commonly expressed by profitability, turnover growth rate, return on investment, return on assets, etc. ${ }^{[1]}$ Non-financial indicators includes relative market share, the relative degree of brand recognition, customer satisfaction, customer loyalty, etc. Financial indicators and non-financial indicators are the important indicator of organizational performance assessment. In the past, some scholars advocate that organizational performance can be measured by one single indicator, such as profit, this performance of a single variable measurement is more easily to analysis and investigate. But it will reduce the breadth and system concept of organizational performance on that we use a single variable to assess the performance, and different organizations should be measured by different indicators, for it is reasonable that organizational performance should be expressed by a wide range of indicators ${ }^{[2]}$.

In addition, the indicators of organizational performance measurement can be divided into subjective indicators and objective indicators. That the subjective indicators of performance can be measured by the scale which are filled by respondents with their subjective perception. And objective indicators refers to exact data, such as the percentage of sales growth or profits, etc. ${ }^{[3]}$ In the current study, researchers use subjective indicators to measure organizational culture because it is difficult to measure objective indicators.

\section{B Organizational culture and organizational performance}

Organizational culture is the organization of all employees in the long-term business and development fostered, and abide by the highest goals, values, basic beliefs and codes of conduct $^{[4]}$. Organizational culture ,In the past two decades, the majority of scholars have developed many tools for measuring organizational culture. For instance: Hofstede's ${ }^{[5]}$ the Multidimensional Model of Organizational Cultures; Denison's ${ }^{[6]}$ Organizational Culture Questionnaire; Quinn\& Cameron's $^{[7]}$ Organizational Culture Assessment 
Instrument(OCAI), Zhengboxun's Values in Organizational Culture Scale.

Both organizational culture and organizational performance are the paradoxical unity. In general conditions, rapid development, and stable are he organization's desire, both effective, and flexible is the organization's desire. The internal focus culture may create a good working atmosphere, but organization may miss important external information; The external focus culture may help organization to seize opportunities and avoid external threats, but organization may lack the corresponding internal systems and mechanisms for cooperation. An effective should contain internal focus and integration, external focus and differentiation, flexibility and discretion, Stability and control ${ }^{[6]}$.

This study of organizational culture based on organizational level, the focus is to explore the relationship between different types of culture and performance. The development of Organizational Culture Assessment Instrument which was build by Quinn \& Cameron was based on organizational effectiveness indicators, containing opposite and unified values, so, this paper uses the theoretical framework of Cameron and Quinn's to describe the organizational culture types.

Cameron \& Quinn's ${ }^{[7]}$ Organizational Culture Assessment Instrument was based on Competing Values Framework which proposed by them in the 1980s. This framework consists of two continuum of values, there are two opposing core values which are "Flexibility and Stability" and "Internal focus and External focus" in each ends of the continuum. Each dimension represents two opposing and conflicting values, so it was called Competing Values Framework. The distinction between the two dimensions of the four quadrants represent different types of organizational culture: adhocracy, clan, hierarchy, market. Different types of organizational culture will have an impact on organizational performance. The general assumption can be examined from the following four areas.

The organization with adhocracy culture encourages employees to proceed creative work and promote the spirit of adventure and innovation. In order to adapt the rapid changes in external information, organization encourage to create a learning culture. In this culture, the organization's managers can access useful information continuously and draw the collective opinions, meanwhile, according to the changing of external conditions, organization can change their form and mode of operation. So, this study put forward the hypothesis 1:adhocracy culture has a positive impact on financial performance and market performance.

The organization with clan culture emphasizes "stability", the organization's employees lack adventurous spirit and passion. they pursue to live safely. In order to pursuit of stable operation, organization does not encourage their employees to proceed creative work. In this culture, it is difficult for organization's managers to obtain useful information from the outside environment; It is also difficult for their employees to put themselves into the performance of the team, because the employees lack the innovative spirit. So, this study put forward the hypothesis 2:clan culture has a negative impact on financial performance and market performance.
The organization with hierarchy culture manages their staff with more stringent rules and regulations, In this culture, hierarchy is more standardized. As the work environment is more formal and with more level, the communication channels are not very smooth. Organization managers obtain useful information from the grassroots, while they lack keen observation about external market. So, this study put forward the hypothesis 3:hierarchy culture has a negative impact on financial performance and market performance.

The organization with market culture encourages employees to compete with each other and encourages competitive spirit. because the external information change frequently, the organization's staff emphasizes to enhance their capable of learning knowledge, and the organization encourages to create a learning and competitive culture. In this culture, it is easy for organization's managers to access useful information and make decision quickly, they can also use the healthy competition among the staff to improve their competitiveness. So, this study put forward the hypothesis 4:market culture has a positive impact on financial performance and market performance.

\section{Research Design}

\section{A Variable measurement}

Organizational performance. According to Kohli. Jaworski, Christian Homburg and other scholar's point, this paper divided organizational performance into financial performance and market performance. Financial performance can be measured by three dimensions which are sales, ratio of sales and return on investment. Market performance can be measured by three dimensions which are customer satisfaction, market share and customer retention rate. In order to obtain the uniform standards which judged by the interviews, questionnaire took "the average level of the same industry" as the reference system to judge the relationship between the level of their organizational performance and the average level of other same industry's organizational performance. The questionnaire was used to 5 point Likert scale: 1 means very low and 5 is very high.

Organizational culture. According to the Chinese language and the experience of management, the design of the questionnaire survey based on Organizational Culture Assessment Instrument which was widely used at home and abroad. Questionnaire describe the organizational culture from 6 aspects: characteristics of leadership, leadership style, features of employee management cohesive source, strategic emphasis and criterion of success. Each side has 4 description and represented each of 4 types of culture. The OCAI has stable reliability and validity. The calculation results of survey data showed that clan cronbach $a=0.89$,adhocracy cronbach $\mathrm{a}=0.86$,hierarchy cronbach $\mathrm{a}=0.85$,market cronbach $\mathrm{a}=0.81$,each measurement projects of load in the corresponding factor is higher than 0.6 .

\section{B Sample survey and variable information}

Sample survey. Sample selection, the survey sample came from 25 enterprises of 9 provinces such as Guangdong, Jiangsu 
and Jilin, etc., the scope of 11 industries such as finance, manufacturing and insurance, etc.; Investigation method, by the way of visit and email to sent out questionnaires, the author investigated 25 enterprises which included visiting 16 enterprises and distributing email 8 enterprises; Sample recovery, 360 questionnaires were sent out and 349 available questionnaires were retrieved, the effective return rate of questionnaires is $96.9 \%$, the basic information of samples saw Table 1.

Table 1. basic information of samples $(\mathrm{N}=349)$

\begin{tabular}{|c|c|c|c|}
\hline & Category & Population & Percent(\%) \\
\hline \multirow{3}{*}{ Gender } & $\mathrm{M}$ & 227 & 63.1 \\
\cline { 2 - 4 } & $\mathrm{W}$ & 133 & 36.9 \\
\hline \multirow{3}{*}{ Education } & High school & 16 & 4.4 \\
\cline { 2 - 4 } & College & 58 & 16.1 \\
\cline { 2 - 4 } & Undergraduate & 204 & 56.7 \\
\cline { 2 - 4 } & Postgraduate & 82 & 22.8 \\
\hline \multirow{3}{*}{$\begin{array}{c}\text { Nature of } \\
\text { enterprise }\end{array}$} & State owned & 16 & 72 \\
\cline { 2 - 4 } in the enterprise & Private & 9 & 36 \\
\cline { 2 - 4 } & $1-4$ years & 117 & 32.5 \\
\cline { 2 - 4 } & 5-9 years & 105 & 29.2 \\
\cline { 2 - 4 } & $10-15$ years & 77 & 21.4 \\
\hline
\end{tabular}

Variable information. The variables of organizational performance and organizational culture were analyzed by descriptive statistic, the results of statistical descriptive analysis saw Table 2 and 3.

Table 2. the results of descriptive statistic analysis on organizational performance

Mean S.D Financial performance Market performance \begin{tabular}{|l|l|l|}
\hline Financial performance & 3.55 & 1.84 \\
\hline
\end{tabular} \begin{tabular}{|l|l|l|}
\hline Market performance & 4.13 & 1.02 \\
\hline
\end{tabular} $* * \mathrm{P}<0.01$

Table 3. the results of descriptive statistic analysis on organizational culture

\begin{tabular}{|c|c|c|c|c|c|c|}
\hline & Mea-n & S.D & $\begin{array}{l}\text { Adhocr- } \\
\text { acy }\end{array}$ & Clan & Hierarc-hy & Market \\
\hline Adhocra-cy & 3.70 & 1.06 & & & & \\
\hline Clan & 3.91 & 1.57 & $\begin{array}{l}0.39 \\
(* *)\end{array}$ & & & \\
\hline Hierarch-y & 3.17 & 0.92 & $\begin{array}{l}0.50 \\
(* *)\end{array}$ & $\begin{array}{l}0.37 \\
(* *) \\
\end{array}$ & & \\
\hline Market & 3.66 & 1.46 & $\begin{array}{l}0.34 \\
(* *)\end{array}$ & $\begin{array}{l}0.44 \\
(* *)\end{array}$ & $\begin{array}{l}0.30 \\
(* *)\end{array}$ & \\
\hline
\end{tabular}

\section{Analysis and Conclusion}

\section{A Correlation analysis}

The author used SPSS statistical analysis software to obtain the correlation coefficient between organizational culture types and different dimensions of organizational performance, table 4 lists the correlation coefficient and the statistical test value. From table 4 we can see(1)The correlation coefficient of adhocracy culture and financial performance is 0.10 , the correlation coefficient of adhocracy culture and market performance is 0.16 , and the probabilities of making the hypothesis testing of correlation coefficients equal 0 were less than 0.01. Obviously, adhocracy culture has a positive impact on financial performance and market performance. So, hypothesis 1 was verified; (2)The correlation coefficient of clan culture and financial performance is -0.05 , the correlation coefficient of clan culture and market performance is -0.06 , and the probabilities of making the hypothesis testing of correlation coefficients equal 0 were less than 0.05 . Obviously, clan culture has a negative impact on financial performance and market performance. So, hypothesis 2 was verified; (3)The correlation coefficient of hierarchy culture and financial performance is -0.12 , the correlation coefficient of hierarchy culture and market performance is -0.08 , and the probabilities of making the hypothesis testing of correlation coefficients equal 0 were less than 0.05 . Obviously, hierarchy culture has a negative impact on financial performance and market performance. So, hypothesis 4 was verified; (4)The correlation coefficient of market culture and financial performance is 0.11 ,the correlation coefficient of market culture and market performance is 0.05 , and the probabilities of making the hypothesis testing of correlation coefficients equal 0 were less than 0.01. Obviously, market culture has a positive impact on financial performance and market performance. So, hypothesis 3 was verified.

Table 4. the correlation analysis of organizational culture and organizational performance

\begin{tabular}{|c|c|c|c|c|}
\hline & \multicolumn{2}{|c|}{ Financial Performance } & \multicolumn{2}{|c|}{ Market Performance } \\
\hline & $\begin{array}{c}\text { Pearson } \\
\text { correlation }\end{array}$ & Sig.(2-tailer) & $\begin{array}{c}\text { Pearson } \\
\text { correlation }\end{array}$ & Sig.(2-tailer) \\
\hline Adhocracy & $0.10\left(^{* *}\right)$ & 0.00 & $0.16\left(^{* *}\right)$ & 0.00 \\
\hline Clan & $-0.05\left(^{*}\right)$ & 0.04 & $-0.06\left(^{*}\right)$ & 0.02 \\
\hline Hierarchy & $-0.12\left(^{*}\right)$ & 0.04 & $-0.08(*)$ & 0.04 \\
\hline Market & $0.11\left(^{* *}\right)$ & 0.00 & $0.05\left(^{* *}\right)$ & 0.00 \\
\hline
\end{tabular}

\section{B Regression analysis}

Regression analysis can deeply explore the degree of the organizational culture type's effect on organizational performance. The results primary report the standardized regression coefficient, the value of the regression coefficient $t$ and the significance test value $t$. The organizational performance can be measured by financial performance and market performance, so before the regression analysis, in order to facilitate analysis, we should hand the data into one dependent variables.

Table 5. the regression analysis of organizational culture and organizational performance

\begin{tabular}{|c|c|c|c|}
\hline \multirow{2}{*}{} & \multicolumn{3}{|c|}{ Organizational culture } \\
\cline { 2 - 4 } & beta & $\mathrm{t}$ & Sig. \\
\hline adhocracy & 0.24 & 4.96 & 0.01 \\
\hline clan & -0.11 & -2.05 & 0.04 \\
\hline hierarchy & -0.13 & -2.43 & 0.03 \\
\hline market & 0.17 & 3.97 & 0.02 \\
\hline
\end{tabular}

From the results of the regression analysis above we can see that the standardized regression coefficient beta of adhocracy, clan, hierarchy and market passed the significance test value. This shows that four organizational culture types have impact on organizational performance. Through the observation of beta, we can see that the more an enterprise's 
organizational culture types tend to the adhocracy, the higher the organizational performance is; The more an enterprise's organizational culture types tend to the clan, the lower the organizational performance is; The more an enterprise's organizational culture types tend to the hierarchy, the lower the organizational performance is; The more an enterprise's organizational culture types tend to the market, the higher the organizational performance is. And adhocracy and market had greater impact on organizational performance.

\section{References}

[1] Dess G G,Robinson R B, Measuring Organizational Performance in the Absence of Objective Measures.Strategic Management Journal, May 1984, pp. 265-273.
[2] Xu Mingbo, Innovation Trends of Corporate Performance Measurement Pattern: Overview and Prospect. Economic Management. 2007, 29(18), pp. 23-28.

[3] Zhang Qianlan, The Empirical Research on the Influence of Market Orientation and Innovation Orientation on Firm Perpormance. A master's degree thesis of Hunan University. Changsha: Business School Hunan University, 2005, PP. 14-15.

[4] Zhang de, Corporate culture. Beijing:Tsinghua University Press, 2003.

[5] Hofstede G, Neuijen B, Ohayv D and Sanders G, Measuring organizational cultures: a qualitative and quantitative study across 20 cases. Administrative Science Quarterly, 1990, 35, PP. 286-316.

[6] Denison, Daniel R. and Mishra, Aneil K, Toward a theory of organizational culture and effectiveness. Organization Science, June 1995, PP. 204-223.

[7] Cameron K S, Quinn R E Diagnosing and changing organizational culture: Based on The Competing Values Framework. New York: Addison-Wesley Press,1998. 